\title{
Diagnostic and Treatment Strategies for COVID-19
}

\author{
Humzah Jamshaid, ${ }^{1}$ Fatima Zahid, ${ }^{1}$ Intisar ud Din, ${ }^{2}$ Alam Zeb, ${ }^{3}$ Han Gon Choi, ${ }^{4,5}$ \\ Gul Majid Khan, ${ }^{1,5}$ and Fakhar ud Din $^{1,5}$ (D)
}

Received 3 May 2020; accepted 13 July 2020; published online 3 August 2020

\begin{abstract}
The world is facing lockdown for the first time in decades due to the novel coronavirus COVID-19 (SARS-CoV-2) pandemic. This has led to massive global economic disruption, placed additional strain on local and global public health resources and, above all, threatened human health. We conducted a review of peer-reviewed and unpublished data, written in English, reporting on the current COVID-19 pandemic. This data includes previously used strategies against infectious disease, recent clinical trials and FDA-approved diagnostic and treatment strategies. The literature was obtained through a systematic search using PubMed, Web of Sciences, and FDA, NIH and WHO websites. Of the 98 references included in the review, the majority focused on pathogen and host targeting, symptomatic treatment and convalescent plasma utilization. Other sources investigated vaccinations in the pipeline for the possible prevention of COVID-19 infection. The results demonstrate various conventional as well as potentially advanced in vitro diagnostic approaches (IVD) for the diagnosis of COVID-19. Mixed results have been observed so far when utilising these approaches for the treatment of COVID-19 infection. Some treatments have been found highly effective in specific regions of the world while others have not altered the disease process. The responsiveness of currently available options is not conclusive. The novelty of this disease, the rapidity of its global outbreak and the unavailability of vaccines have contributed to the global public's fear. It is concluded that the exploration of a range of diagnostic and treatment strategies for the management of COVID-19 is the need of the hour.
\end{abstract}

KEY WORDS: COVID-19; SARS-CoV-2; diagnosis; treatment strategies; pandemic; public health.

\section{INTRODUCTION}

SARS-CoV2, a deadly virus belonging to the family Coronaviridae, primarily targets the pulmonary system and manifests with symptoms of moderate to high fever, dry cough and difficulty breathing, pneumonia, and respiratory distress. The emergence and outbreak of microbial infections depends upon several factors including the mutability of microbes, the distraction of human and microbial environments, and human experiments on new microbes. The epicentre of COVID-19 infection was in Wuhan, in the city

\footnotetext{
${ }^{1}$ Department of Pharmacy, Nanomedicine Research Group, Quaid-iAzam University, Islamabad, 45320, Pakistan.

${ }^{2}$ College of Resources and Environment, Huanzhong Agricultural University (Hazu), Wuhan, Hubei, China.

${ }^{3}$ Riphah Institute of Pharmaceutical Sciences, Riphah International University, Sector G-7/4, Islamabad, 44000, Pakistan.

${ }^{4}$ College of Pharmacy \& Institute of Pharmaceutical Science and Technology, Hanyang University, 55 Hanyangdaehak-ro, Sangnokgu, Ansan, 15588, South Korea.

${ }^{5}$ To whom correspondence should be addressed. (e-mail: hangon@hanyang.ac.kr; gmkhan@qau.edu.pk; fudin@qau.edu.pk)
}

of Hubei, China, from where the disease surged on December 29, 2019, and spread quickly to the rest of the China $(1,2)$. The World Health Organisation reported COVID-19 as pandemic on March 11, 2020, and declared a Public Health Emergency of International Concern against COVID-19 (3).

Up to today, 8 July 2020, the COVID-19 outbreak has spread to 215 countries as reported by the World Health Organisation. Almost 539,026 deaths have been reported around the globe, with nearly 11,635,939 cases are reported as confirmed cases of COVID-19 infection. The highest number of deaths has been reported in the USA $(129,963)$, followed by Brazil $(65,487)$, Italy $(34,869)$, Mexico $(31,119)$, Spain $(28,388)$, India $(20,642)$, Iran $(11,931)$ and China (4648). In USA, a total of $2,923,432$ people have been infected, which makes it the most affected area in this pandemic (4). These numbers are growing on a daily basis. Unsurprisingly, this sharp upsurge in the number of infected patients has instigated widespread panic among the population. Scientists around the globe have been looking for possible detection and treatment strategies since the beginning of the outbreak. In this regard, the first genome of COVID-19 was published by Prof. Yong-Zhen Zhang and colleagues on 10 January 
2020 (2). However, there is only limited data available on the clinical diagnosis, treatment and control of this deadly virus.

Owing to the devastating conditions of the COVID-19 outbreak, the unavailability of a vaccine and its deadly influence on human health, it is important to understand the available detection tools recently approved by the FDA or health authorities of other advanced countries and possible treatment strategies to fight this lethal virus. We therefore conducted a comprehensive review on potential detection and treatment strategies related to COVID-19. This review will provide a brief description of the clinical diagnosis and therapeutic drug delivery options. Furthermore, this review will provide information on COVID-19 as a basis for further, extensive research. It may also provide a good background for various government and private organisations to develop diagnostic, treatment and preventive strategies against COVID-19 and other such viruses to support public health. Moreover, we aimed to increase knowledge of the clinical expression of COVID-19 infection to further establish and reinforce a timely diagnosis and treatment of the infection in order to reduce mortality rate.

\section{DIAGNOSTICS}

Due to the unavailability of satisfactory treatment and vaccination, the management of COVID-19 depends upon the timely diagnosis and standard (symptomatic) treatment yet. Thus, for timely detection of virus, efficient diagnostic strategies (enlisted in Fig. 1) should be required to opt. The detail of these diagnostics along with clinical manifestation is also discussed below.

\section{Advance In Vitro Diagnostic Approaches}

In vitro diagnostic (IVD) approach relies on either the principle of viral genetic material detection or the host antibody, against COVID-19, detection, in the host specimen. The detailed comparison between these two COVID-19 diagnostic approaches is stated in Table I.

\section{Viral Nucleic Acid Detection}

\section{Real-Time Polymerase Chain Reaction}

For the confirmed diagnosis of COVID-19, viral genetic material identification in the patient's body is strongly recommended. Real-time reverse transcription polymerase chain reaction (RT-PCR) can be used for the detection of COVID-19 nucleic acids in nasopharyngeal swabs, lower respiratory tract secretions, sputum, blood, faeces and other specimens. A graphical illustration of real-time RT-PCR is shown in Fig. 2. At the start of 2020, a German scientist suggested using the RT-PCR test for the detection of SARSCoV-2 as it has high accuracy and precision (8). Conventional RT-PCR for virus detection can sometimes be associated with false negative results, particularly in the early stages of infection. To bypass this issue, more advanced RT-PCR diagnostics are needed (9).

NGS (next generation sequencing) is an alternative approach that can be used for this purpose; fortunately, it is more advanced and rapid compared with PCR (10). The mutation of the pathogen can also be checked by NGS. In order to obtain accurate results, the sample should be taken from the lower respiratory tract (2).

\section{RT-PCR-Based Rapid Test Devices}

Recently, the FDA has given approval for the first rapid detection test kit for COVID-19 detection for use under an Emergency Use Authorisation (EUA) developed by Cepheid. It can detect COVID-19 within approximately $45 \mathrm{~min}$. Samples are collected via nasopharyngeal swab or nasal wash and are prepared in less than $1 \mathrm{~min}$. The technique used in this is RT-PCR and the kit has the required probes, primers and internal controls with it. The GeneXpert ${ }^{\circledR}$ instrument system (mentioned in Table II), present in qualified laboratories in the USA, is currently used to perform this test (12).

\section{Isothermal Nucleic Acid Amplification Assay}

Due to confrontation of inadequate RT-PCR sensitivity for COVID-19 diagnosis, more advanced nucleic acid detection techniques were recently investigated including isothermal technique. It was found suitable for the detection of very low quantity of viral RNA (genetic material) and it can affectively be used as an alternative technique to RT-PCR (16). Two companies have developed the rapid detection devices on the basis of these techniques, stated in Table II. An isothermal nucleic acid amplification-based device developed by Abbott under the trade name of ID Now ${ }^{\circledR}$ has obtained FDA EUA (7).

\section{CRISPR Nucleic Acid Assay}

Another advanced technology for nucleic acid detection is the use of Clustered Regularly Interspaced Short Palindromic Release (CRISPR) using myriad bacterial enzymes such as Cas-12, to detect viral genome. In comparison with real-time RT-PCR, this technique ensures rapidity and better sensitivity for COVID-19 nucleic acid detection (13).

\section{Antibody Detection Immunoassays}

Lateral Flow Immunoassay-Based Kits. Just like the rapid pregnancy strip test, lateral flow immunoassay-based techniques for COVID-19 have been developed for rapid diagnosis (17). This mode of diagnosis requires a significantly low quantity of sample (10 $\mu \mathrm{L}$ of blood) along with a detection time of less than 15 min. A US-based company, BioMedomics, has developed an IgM-IgG-based rapid test kit and obtained approval from the FDA for distribution in the USA. In addition, several other companies have also developed serological testing strips (18). Though the standard COVID-19 test is nucleic acid detection by PCR, these antibody detection-based techniques have comparable sensitivity and selectivity to RT-PCR and are recommended to be used when RT-PCR facilities are not available (19).

Chemiluminescence Immunoassay-Based Kits. Recently, Diazyme in the USA developed a chemiluminescence immunoassay (CLIA)-based IgM and IgG rapid detection test and 


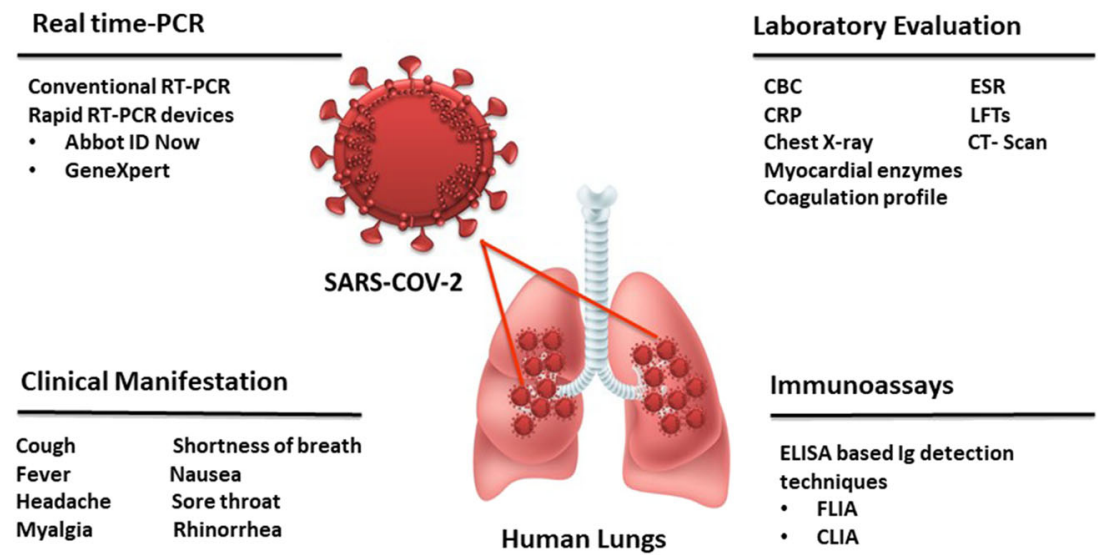

Fig. 1. Diagnostic approaches for COVID-19

also gained FDA EUA. It runs on an automated analyser, with a throughput of 50 tests/h (20). On a similar detection principle, the Chinese company Snibe has developed the MAGLUMI CLIA analyser for the detection of $\operatorname{IgM}$ and $\mathrm{IgG}$ in patient samples (21).

\section{Conventional Diagnostic Approaches}

\section{Physical Examination}

This strategy involves the diagnosis of the disease based upon physical signs and symptoms. Some patients have only mild symptoms with fatigue, and low fever in the absence of pneumonia, whereas patients with severe cases demonstrate dyspnoea, lung crackles and dullness to percussion, as reported by Jin et al. in 2020 (2). Patients with severe disease may progress to acute respiratory distress syndrome, dyspnoea (after 1 week), septic shock, bleeding disorders, difficult to correct metabolic acidosis and even multiple organ failure. Those in severe or critical condition could show a low to moderate fever (22).

\section{Imaging Examination}

CT imaging of the patient is strongly recommended for the diagnosis of patients, as reported by the researchers at Zhongnan Hospital of Wuhan University. The sensitivity of CT scan, however, for COVID-19 diagnosis is appeared to be $97.2 \%$ (23). It has been reported that CT imaging of lesions may exhibit major distributions in the subpleural region or may barely exist along bronchial vascular bundles. A quantitative analysis demonstrated the existence of randomly one to two and often more than three lesions. Their morphology was observed to be nodular, lumpy or patchy. Moreover, the density was found to be mostly uneven with a condensed bronchial wall. Other associated indications vary from air-filled bronchi, enlarged lymph nodes (mediastinal) and rarely pleural effusion $(2,24)$.

Table I. Comparison Between IVD-RT-PCR-Based Technique and Immunoassay-Based Techniques

\begin{tabular}{|c|c|c|}
\hline Parameter & Polymerase chain reaction (PCR)-based techniques & Immunoassay-based kits \\
\hline Sampling & Nasopharyngeal swab, saliva & Blood $(10-20 \mu \mathrm{L})$ \\
\hline Component to be detected & $\begin{array}{l}\text { Envelop }(\mathrm{E}) \text { gene } \\
\text { RNA-dependent RNA polymerase } \\
\text { gene }(5,6)\end{array}$ & Antibodies (IgM-IgG) \\
\hline Stage at which infection detected & $\begin{array}{l}\text { Asymptomatic or subclinical infection } \\
\text { can be detected }\end{array}$ & $\begin{array}{l}\text { Detection is usually when the immune system } \\
\text { starts responding to infection }\end{array}$ \\
\hline Average result time & $\begin{array}{l}\text { Within few hours } \\
\text { Rapid device (Xpert@)—app. } 40-45 \mathrm{~min}\end{array}$ & $\begin{array}{l}10-20 \text { min } \\
\text { CLIA-based kit (designed by DIAZYME) - } \\
50 \text { tests/h }\end{array}$ \\
\hline Specificity & High (5) & High (5) \\
\hline Cost & High & Low \\
\hline Results validity & $\begin{array}{l}\text { High sensitivity to SARS-COV-2 } \\
\text { viral genes (5) }\end{array}$ & $\begin{array}{l}\text { Possibility of false negative results as IgG } \\
\text { level appears in blood approximately } 20 \\
\text { days post-infection* (7) }\end{array}$ \\
\hline
\end{tabular}

PCR- Polymerase chain reaction; CLIA-Chemiluminescence immunoassay; IgM- Immunoglobulin M; IgG- Immunoglobulin G; $R T$-PCR- Reverse Transcriptase- Polymerase chain reaction; SARS-COV-2- Severe Acute Respiratory Syndrome Corona Virus-2 *But recommended to be used when there is fall short in RT-PCR facility 


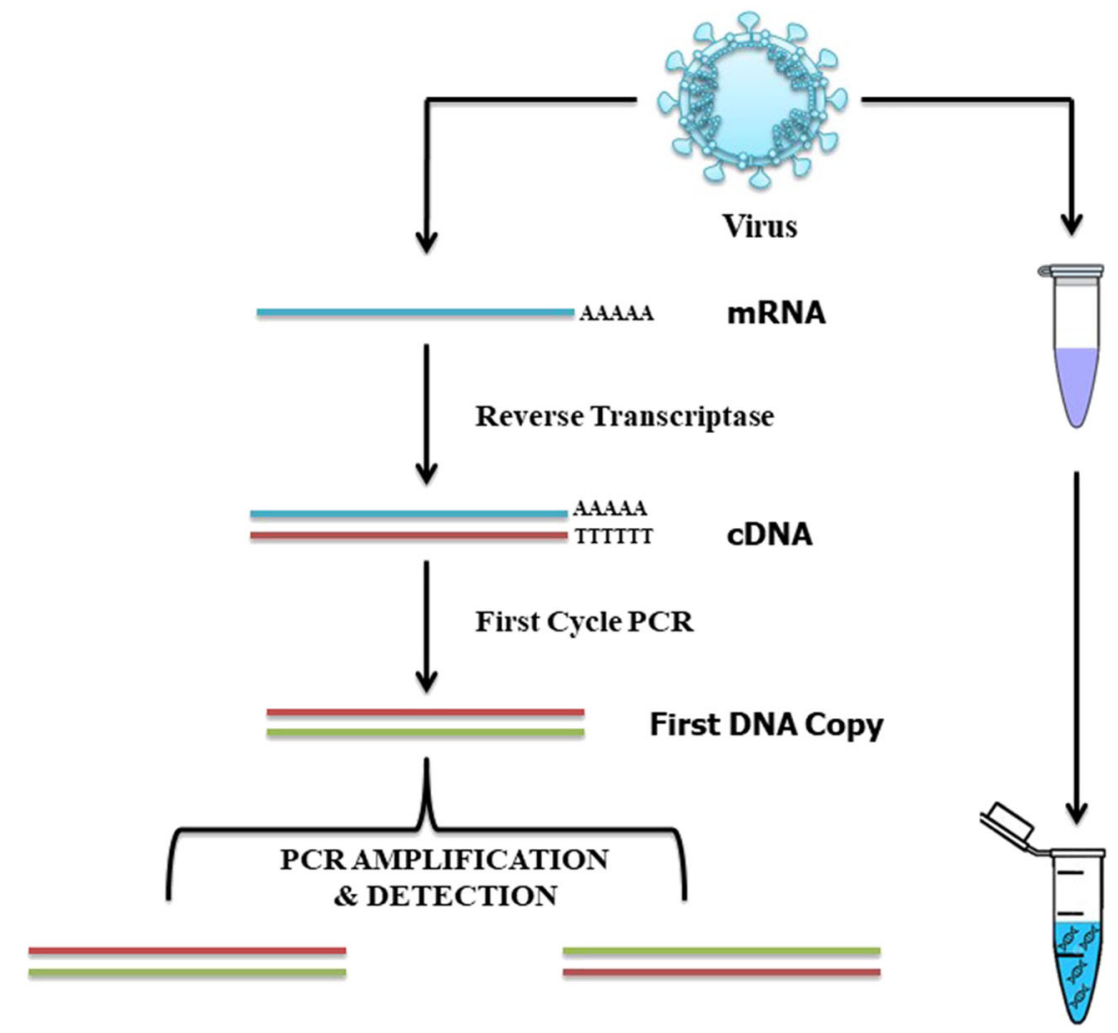

Fig. 2. Graphical illustration of RT-PCR

\section{Laboratory Examination}

Haematological Examination. By assessing haematological variations, COVID-19 can be provisionally diagnosed. As reported by Jin and colleagues, initially the number of lymphocytes decreases, and the number of monocytes remains normal or increases, whereas the total leukocyte count remains normal or decreases with advancement of the disease. In cases where a significant decline is observed in CD4+ and CD8+ $\mathrm{T}$ cells or when the lymphocyte absolute value falls below $0.8 \times 10^{9} / \mathrm{L}$, attention must be given with routine rechecking of blood counts every 3 days (2). Similarly, elevation in muscle and liver enzymes, i.e. myoglobin and lactate dehydrogenase, is observed in some patients (22). Elevation in C-reactive protein and a higher erythrocyte sedimentation rate with normal levels of procalcitonin are also seen in many cases. Elevated D-dimer levels with decreased peripheral blood lymphocytes are observed in severely ill patients (25). Moreover, among critical patients, troponin levels are also elevated. Inflammatory factor levels are also observed to be increased in both severe and critical patients (2).

Table II. Recommended COVID-19 Nucleic Acid Detection Techniques

\begin{tabular}{|c|c|c|c|c|}
\hline Organization conducted the study & Test principle & $\begin{array}{l}\text { Sensitivity } \\
\text { of test }\end{array}$ & $\begin{array}{l}\text { Manufacturer/commercially } \\
\text { available devices }\end{array}$ & Reference \\
\hline $\begin{array}{l}\text { Huazhong University of Science and } \\
\text { Technology, Wuhan, China }\end{array}$ & $\begin{array}{l}\text { Chest CT } \\
\text { RT-PCR }\end{array}$ & $\begin{array}{c}\text { Chest CT } \\
97 \% \\
\text { RT-PCR } \\
59 \%\end{array}$ & - & (11) \\
\hline $\begin{array}{l}\text { Fred Hutchinson Cancer Research Center, } \\
\text { WA, USA }\end{array}$ & Real-time RT-PCR & $84.6 \%$ & $\begin{array}{l}\text { Xpert }{ }^{\circledR} \text { Xpress by Cepheid } \\
\text { Roche Molecular System }\end{array}$ & $(12)$ \\
\hline University of California, San Francisco, USA & CRISPR & $\begin{array}{l}\text { Not } \\
\text { reported }\end{array}$ & $\begin{array}{l}\text { Cepheid Sherlock Biosciences } \\
\text { Mammoth Biosciences }\end{array}$ & $(13)$ \\
\hline Wuhan Institute of Virology, China & $\begin{array}{l}\text { Is othermal nucleic acid } \\
\text { amplification technology }\end{array}$ & $95 \%$ & Abbott® ID Now & $(7,14,15)$ \\
\hline
\end{tabular}

CT- Computed Tomography; RT-PCR-Reverse Transcriptase- Polymerase chain reaction; CRISPR- Clustered Regularly Interspaced Short Palindromic Release 
Pathological Changes Observed from Biopsies and Autopsies. During the recent COVID-19 pandemic, autopsy and biopsy studies confirmed that the pathological basis of this disease is alveolar damage, with the organisation of exudates in alveoli and fibrosis in the lungs. Lymphocytopenia and necrosis can be observed in the spleen and lymph nodes. Necrosis can also be observed in myocardial tissues, but the observed heart and liver changes can be attributed or limited to underlying diseases $(22,26)$. However, these invasive techniques are not recommended for routine diagnosis.

Additional Laboratory Testing. For monitoring the improvement of a patient's condition, other laboratory tests such as blood gas analysis (oxygenation), liver and kidney function tests, myocardial enzymes, erythrocyte sedimentation rate (ESR), C-reactive protein (CRP), percutaneous nephrostomy (PCN), lactate dehydrogenase (LDH), D-dimer, urinalysis, coagulation image, 11 items of the tuberculosis (TB) subgroup, inflammatory factors (IL-6, IL-10, TNF- $\alpha$ ), complement and anti-acid staining can commonly be used. Moreover, CRP and PCN can be assessed. The existence of a bacterial infection in the lungs should be determined as these inflammatory factors are commonly elevated in such sort of infection $(2,22,25)$.

\section{TREATMENT STRATEGIES}

\section{Pathogen-Targeting Strategies}

Despite the rapid progression of the COVID-19 pandemic, unfortunately, anti-virals or other drugs still are yet to be approved for the treatment of COVID-19. However, the sudden outbreak has compelled the repurposing of already available drugs (described in Fig. 3) that have been documented to possess activity against HIV, MERS and SARSCOV-1.

\section{Anti-Virals}

COVID-19 is, in fact, an RNA betacoronavirus, and its genomic sequence and various enzymes are similar (80-90\%) to those of the severe acute respiratory syndrome (SARS) and Middle East respiratory syndrome (MERS) coronaviruses. The use of existing anti-viral may become the mainstay to reduce viral load and treat the infection. Multiple pre-existing anti-viral agents have been tried to assess their in vitro anti-COVID-19 properties (27). Protease inhibitors possess considerable inhibitory activity against RNA viruses. Thus, on the basis of lopinavir-ritonavir in vitro inhibitory activity reported against acute respiratory distress syndrome caused by SARS and MERS, an open-label, randomised control trial (ChiCTR2000029539) was conducted in China (28). Unfortunately, the results were not significantly different between the two randomised groups (one group treated with lopinavir-ritonavir and other with standard care protocols) (29). Favipiravir, remdesivir and ribavirin, i.e. nucleoside structural analogues, have also been reported to possess in vitro inhibitory activity against COVID-19. Recently, a study was conducted on five anti-viral agents to determine their activity regarding COVID-19 inhibition, i.e. preventing viral incorporation and multiplication inside Vero E6 cells. Among them, remdesivir was found to possess significant anti-viral activity at lower values of the half-maximal effective concentration $\left(\mathrm{EC}_{50}\right)$, i.e. $0.77 \mu \mathrm{M}$, along with the antimalarial agent chloroquine, with an $\mathrm{EC}_{50}$ value of $1.13 \mu \mathrm{M}$ (30).

Remdesivir, developed by Gilead Sciences, a US-based enterprise, has historically been used for eliminating Ebola virus (31). It is a broad-spectrum investigational anti-viral agent, currently progressing through a double-blinded placebo control trial as well as a phase III open-label clinical trial, due to the abovementioned success in vitro Vero E6 cell experiments. In addition, it is currently being used on COVID-19 patients in non-trial areas of the USA and other countries (NCT04292899) (32). Due to its promising effects against COVID-19, Gilead Sciences have agreed to a pact to allow Pakistan's national pharmaceutical company, Ferozsons Laboratories Ltd., to carry out production for the country's utilisation and export (33). It is, fortunately, the only recommended anti-viral drug which can be used in patients with low oxygen saturation (below 94\%) and critical patients on artificial ventilation. But its use in mild symptomatic patients is not recommended. The recently conducted trial in hospitalised patients has clearly demonstrated a significantly reduced mortality rate (from 11 to $7.1 \%$ ) with remdesivir use (34). Due to adequate evidence from the literature, a small monocular agent having anti-viral activity against influenza virus strains, adenovirus, rhinovirus and several other RNA and DNA viruses, Arbidol, also appears to possess significant anti-COVID-19 activity and is going through a phase IV clinical trial at present (NCT04260594) (35). In addition to that, another randomised control trial has been conducted in China comparing the cure rate and 7-day recovery rates in patients randomly allocated to two groups, one receiving favipiravir and the other receiving Arbidol treatment. The clinical recovery rate of favipiravir was found to be superior, i.e. $61.21 \%$, and was better than that of Arbidol (51.67\%) (36). Most recently, another broad spectral anti-viral drug, Nhydroxycytidine and its prodrug, has been found to have promising anti-viral ability against various strains of the Coronaviridae family, i.e. SARS-CoV-2, MERS-COV and SARS-COV, and has qualified as candidates for human clinical trials. Furthermore, these studies utilised human airway epithelial cells (HAE) and Calu-3 cells, in addition to Vero E6 cells (37).

\section{Anti-Malarials}

Chloroquine, an old drug renowned for its anti-malarial and anti-rheumatic uses, has been found to exhibit substantial anti-COVID-19 activity, at a low $\mathrm{EC}_{50}$, i.e. $1.13 \mu \mathrm{M}$ (30). These adequate in vitro results on chloroquine urged scientists to move this drug toward human clinical trials. Due to its low $\mathrm{EC}_{50}$ and higher cytotoxic concentration $\mathrm{CC}_{50}$, chloroquine was introduced into human clinical trials conducted at more than 10 hospitals in China. The results were found to be promising in terms of lowering the viral load and disease duration as well as preventing the exacerbation of COVID-19 pneumonia (38). The probable mechanism by which chloroquine exhibits anti-COVID-19 effects is its 


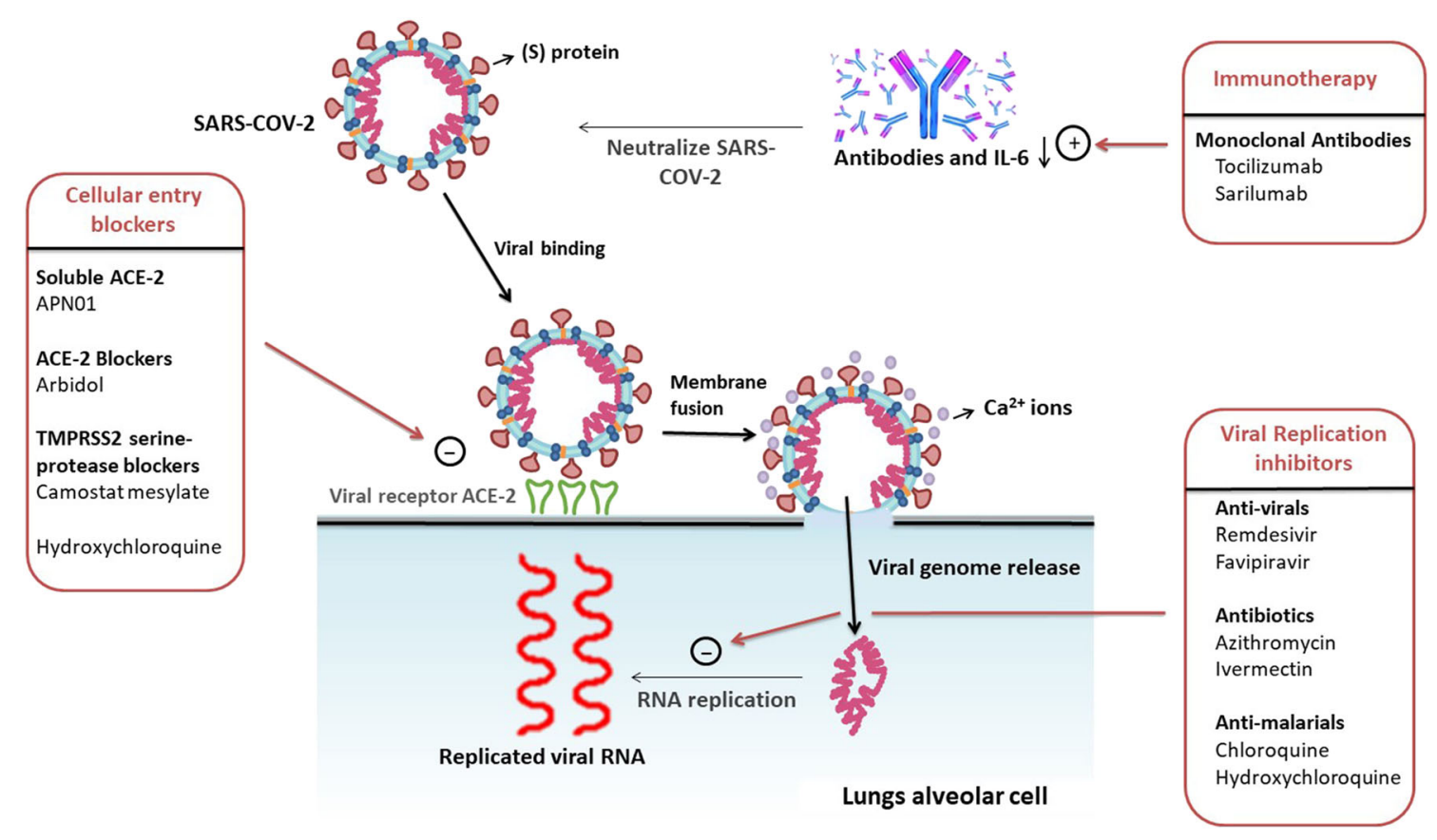

Fig. 3. Mechanism of action of major repurposing agents against COVID-19

ability to inhibit the fusion and entry of the virus into the host cell (39). However, due to the toxicity-mediated limitations of chloroquine, it has not been introduced into clinical trials by the NIH.

Hydroxychloroquine, a suitable alternative shown to be considerably less toxic (app. 40\%) and having comparable anti-COVID-19 activity at its parent drug, is currently undergoing randomised controlled phase III clinical trials (NCT04261517) (40,41). The underlying anti-viral mechanisms of hydroxychloroquine are an increase in endosomal $\mathrm{pH}$ and the prevention virus entry into the target cell (42). Unfortunately, no convincing evidence was obtained during the recent trials to support the curing use of chloroquine and hydroxychloroquine in COVID-19 (43).

\section{Antibiotics}

An open-label randomised control trial was performed in China comparing post-treatment virus load in three randomised groups treated with hydroxychloroquine and azithromycin, hydroxychloroquine alone and standard care. The results of this study clearly identified the superiority $(100 \%)$ of combined treatment over hydroxychloroquine monotherapy (57.1\%) and standard care (2020-000890-25) (44). However, the results of non-randomised, observational study recently carried out in Michigan, USA, suggesting the combined use of hydroxychloroquine and azithromycin in COVID-19 patients is associated with significant reduction in viral load and mortality rate. However, results are not much practical due to numerous limitations of the study and negating current NIH recommendations, suggesting to avoid their use in COVID-19 (45). According to recent updates, carrimycin, another macrolide, is undergoing a phase IV clinical trial under the direction of Ronghua Jin at Beijing YouAn Hospital (NCT04286503) (46).

\section{Anti-Parasitics}

Nitazoxanide is an agent, previously indicated as antiparasitic drug, that also exhibits prominent COVID-19 inhibitory activity, but with effects inferior to those of remdesivir and chloroquine (30). Recently, Australian researchers have demonstrated the pronounced in vitro antiSARS-CoV-2 activity of ivermectin, which is also active against human immunodeficiency virus (HIV) and dengue virus. This anti-parasitic agent has been found to significantly reduce viral RNA levels, identified using RT-PCR, at a concentration of approximately $2 \mu \mathrm{M}$, possibly owing to the inhibition of IMP $\alpha / \beta 1$, a viral protein carrier involved in replication $(47,48)$.

\section{Novel Small Molecule Anti-COVID-19 Drugs-Blocking Cellular Entry}

The need of the hour is to develop novel and effective anti-COVID-19 agents because of the expanding spectrum of COVID-19 infection throughout the world. Camostat mesylate, a potent protease inhibitor previously approved in Japan for various indications such as pancreatitis and flu, possesses considerable blocking activity with regarding to viral entry into the host cell via the lysis of TMPRSS2, a serine protease that interacts with the COVID-19 spike (S) protein (49). Unfortunately, there is a lack of data, studies and trials on this innovative drug against COVID-19. Another entity, Arbidol (umifenovir), is believed to inhibit COVID-19 endocytosis into the host cell. This is why Arbidol is currently enrolled in several clinical trials against COVID-19 (50). The Chinese clinical trial agencies along with the NIH are both conducting trials on the efficacy of Arbidol, either alone or in combination with the protease inhibitor favipiravir (NCT04260594, ChiCTR2000030254) (36). 
Soluble ACE2 parenteral administration results in the binding of SARS-CoV-2 spike protein, followed by inhibition of cellular endocytosis (51); this, in turn, would result in pronounced alleviation of lung cellular injury. On the basis of these optimistic findings, a human recombinant ACE2 (APN01) was designed and shown to lead to a prominent reduction in AN-II-mediated lung injury and IL-6 levels. This evidence was sufficient to support a RhACE2 clinical trial. Currently, Apeiron Biologics are sponsoring clinical trials on the efficacy and safety of APN01, which are currently in phase II (NCT04335136) (52).

\section{Host-Targeting Strategy_Immunity Modifiers}

Natural Killer Cells. It has been hypothesised that there is high death rate among the geriatric population owing to their inadequate immune response. Thus, simply stabilising the patient's immune profile could be helpful toward an earlier resolution of COVID-19 symptoms. Chen et al. claimed that CD4+ T cells, CD8+ T cells and antibodies were found to reduce the symptoms associated with SARS-COV (53). Thus, natural killer (NK) cells may be a reasonable candidate for clinical trials currently in phase I (safety and efficacy assessment) at present (NCT04280224) (54).

Monoclonal Antibodies. Monoclonal antibodies (mAbs) usually alter the immune system response of the host organism, i.e. a reduction in the IL-6 plasma level, which is often elevated in COVID-19 patients on mechanical ventilation (55). However, the exact mechanism by which mAbs work against COVID-19 is unclear. Tocilizumab, a monoclonal antibody clinically approved for several autoimmune disorders, has been evaluated in terms of efficacy and response either alone or in combination with favipiravir. Several randomised studies are being carried out in China and the USA (still ongoing) (NCT04315480) (56). Moreover, Regeneron Pharmaceuticals, in collaboration with Sanofi, are evaluating the safety and efficacy of sarilumab among hospitalised COVID-19 patients, now in phase II (NCT04315298) (57).

mAbs also have clinical significance in myriad malignancies, i.e. advanced colorectal cancer, non-small cell carcinoma of the lung, renal cell carcinoma and breast cancer. For example, bevacizumab impairs angiogenesis by antagonising vascular endothelial growth factor (VEGF), which is considered to be responsible for pulmonary oedema in acute respiratory distress $(58,59)$. This opportunistic strategy to curb the symptoms of severe COVID-19 is currently undergoing phase II clinical trials (NCT04275414) by the NIH and in Wuhan, China (60).

Interferon- $\alpha$ and Corticosteroids. Due to the structural similarities between SARS-CoV-1 and SARS-CoV-2, interferon- $\alpha$ (INF- $\alpha)$ may boost SARS-CoV-2 patient innate immunity. In order to verify this, China has launched clinical trials to treat SARS-CoV-2 patients using combination therapy with INF- $\alpha$ and ribavirin (ChiCTR2000029387) (61). Use of the corticosteroid therapy for treatment and/or reducing the duration of COVID-19 infection was previously questionable due to a lack of clinical evidence (62). However, the results of the recent studies, a pre-test post-test quasi experiment carried out in Michigan and a study conducted in Greece, transparently suggested the beneficial impacts of corticosteroid use in critically ill COVID-19 patients having hyperactive immune system also termed as "cytokine syndrome" $(63,64)$. The recommendations about the use and dosing of dexamethasone for COVID-19 patients are provided by NIH. These recommendations, however, suggested the initiation of steroids in COVID-19 patients on supplemental oxygen and artificial ventilation only (65). Zongji Hospital has sponsored a clinical trial registered with the NIH to assess the safety of INF- $\alpha 2 \beta$ (NCT04293887) and is currently in early phase I (66).

Miscellaneous Agents. Thalidomide, an immunomodulatory, anti-fibrotic and anti-inflammatory drug, has previously been indicated by the US FDA for the treatment of erythema nodosum leprosum, systemic lupus erythematous, inflammatory bowel disease, cystic fibrosis, heart failure and several malignant anomalies (67). The anti-viral activity of thalidomide has been reported, leading to a surge in cellular immunity, i.e. CD8+ T cells against cytomegalovirus (CMV) (68). Due to the enhancement of cellular immunity and significant reduction in TNF- $\alpha$ levels, it is presently undergoing a randomised control clinical trial (NCT04273529) in China (69,70). Fingolimod is an oral sphingosine 1-phosphate receptor activator, currently being utilised for the treatment of multiple sclerosis. It has immune system modifying potential and leads to a significant reduction in peripheral lymphocytes (71). Informed by these characteristics, a clinical trial to assess the efficacy and safety of fingolimod is in progress (NCT04280588) (72) (Table III).

\section{Symptomatic Treatment Strategies}

\section{Mild Infection}

Mild symptomatic COVID-19 patients (with fever > $37.5^{\circ} \mathrm{C}$, fatigue but no dyspnoea), suspected or confirmed cases, should be isolated in quarantine. Moreover, symptomatic relief is recommended. The fever is usually treated with paracetamol or non-steroidal anti-inflammatory drugs, and no specific treatment is suggested at this stage. Additionally, Chinese health workers and doctor also recommend the use of Chinese traditional medicine for the management of patient symptoms (79). European guidelines, however, have supported the use of hydroxychloroquine (HCQ) in patients with confirmed COVID-19. The details are shown in Table IV (81).

\section{COVID-19 Pneumonia}

For patients experiencing not only cough and fever but also increased respiratory rate and pulmonary infiltrates, aggressive symptomatic management is required. Such cases should be given broad-spectrum antibiotics to prevent opportunistic pulmonary infections along with adequate oral hydration. For the purpose of reducing pulmonary secretions, Chinese studies have recommended the use of selective M3 blockers as well. Moreover, anti-COVID-19 specific 
Table III. Promising Anti-COVID-19 Repurposing Treatment Options-Completed and Undergoing Clinical Trials

\begin{tabular}{|c|c|c|c|c|c|}
\hline $\begin{array}{l}\text { Anti-COVID-19 } \\
\text { repurposing options }\end{array}$ & $\begin{array}{l}\text { In vitro anti- } \\
2019- \\
\text { nCOV activity } \\
\text { determined }(+) \\
\text { or not }(-)\end{array}$ & Trial registration no. & $\begin{array}{l}\text { Current phase } \\
\text { of trial }\end{array}$ & $\begin{array}{l}\text { Regimen using/ } \\
\text { used in clinical } \\
\text { trial } / \mathrm{s}\end{array}$ & Reference \\
\hline Lopinavir + ritonavir & + & ChiCTR2000029539 & $\begin{array}{l}\text { Completed } \\
\text { (rejected) }\end{array}$ & $\begin{array}{l}\text { Lopinavir: } 400 \mathrm{mg} \text { PO } \\
\text { Ritonavir: } 100 \mathrm{mg} \\
\text { PO BD for } 14 \text { days }\end{array}$ & $(28)$ \\
\hline Favipiravir & + & ChiCTR2000030254 & $\begin{array}{l}\text { Completed } \\
\text { (recommended } \\
\text { for use in China } \\
\text { and Japan) }\end{array}$ & $\begin{array}{l}1600 \mathrm{mg} / \text { per dose } \mathrm{PO} \\
\text { bid for day } 1, \\
\text { followed by } 600 \mathrm{mg} / \mathrm{dose} \\
\text { PO bid until the end of } \\
\text { the trial }\end{array}$ & (73) \\
\hline Remdesivir & + & NCT04292899 & Phase III & $\begin{array}{l}200 \mathrm{mg} / \text { dose OD IV for } \\
1 \mathrm{day} \text { followed by } \\
100 \mathrm{mg} / \text { dose OD IV for } \\
\text { the next } 4-9 \text { days }\end{array}$ & $(32)$ \\
\hline Arbidol & - & NCT04260594 & Phase IV & $\begin{array}{l}\text { Two tablets PO TID for } \\
10-14 \text { days }\end{array}$ & $(35)$ \\
\hline $\begin{array}{l}\text { Chloroquine } \\
\text { phosphate }\end{array}$ & + & ChiCTR2000029542 & - & $\begin{array}{l}500 \mathrm{mg} / \text { dose PO BID for } \\
\text { not more than } 10 \text { days }\end{array}$ & (74) \\
\hline Hydroxychloroquine & + & $\begin{array}{l}\text { ChiCTR2000029559 } \\
\text { NCT04261517 }\end{array}$ & Completed & $200 \mathrm{mg} /$ dose TID PO for 5 days & $(41)$ \\
\hline Carrimycin & - & NCT04286503 & Phase IV & - & $(46)$ \\
\hline $\begin{array}{l}\text { Hydroxychloroquine- } \\
\text { azithromycin }\end{array}$ & - & $\begin{array}{l}\text { French national agency for drug } \\
\text { safety: 2020-000890-25 }\end{array}$ & Completed & $\begin{array}{l}\text { Hydroxychloroquine: } \\
200 \text { mg PO TID for } 10 \text { days } \\
\text { Azithromycin: } 500 \mathrm{mg} \text { PO } \\
\text { for day } 1 \text { followed by } 250 \\
\text { mg daily for next } 4 \text { days }\end{array}$ & $(44)$ \\
\hline Tocilizumab & - & $\begin{array}{l}\text { ChiCTR2000029765 } \\
\text { NCT04315480 }\end{array}$ & $\begin{array}{l}\text { Completed } \\
\text { Phase II }\end{array}$ & $\begin{array}{l}\text { 4-8 mg/kg IV diluted in NS } \\
\text { (single dose) }\end{array}$ & $(56,75)$ \\
\hline Sarilumab & - & NCT04315298 & Phase II & Single dose IV & $(57)$ \\
\hline Bevacizumab & - & NCT04275414 & Phase II & $\begin{array}{l}500 \mathrm{mg} \text { in } 100 \mathrm{ml} \mathrm{NS} \\
\text { IV rip }\end{array}$ & $(60)$ \\
\hline $\begin{array}{l}\text { Favipiravir }+ \\
\text { tocilizumab }\end{array}$ & - & ChiCTR2000030894 & - & $\begin{array}{l}\text { Favipiravir: } 1600 \mathrm{mg} / \text { dose } \\
\text { BD for } 2 \text { days followed } \\
\text { by } 600 / \text { dose BD for } 7 \text { days } \\
\text { Tocilizumab: } 4-8 \mathrm{mg} / \mathrm{IV}\end{array}$ & $(76)$ \\
\hline $\begin{array}{l}\text { INF- } \alpha+\text { ribavirin, } \\
\text { INF- } \alpha+\text { ribavirin }+ \\
\text { LPR/RTR }\end{array}$ & - & ChiCTR2000029387 & Not completed & $\begin{array}{l}\text { INF- } \alpha \text { : atomised } \\
\text { inhalation, } 5 \text { million } \\
\text { U/50 } \mu \mathrm{g} \text { per dose, } \\
\text { BID for } 14 \text { days }\end{array}$ & $(61)$ \\
\hline INF- $\alpha 2 \beta$ & - & NCT04293887 & Phase I & $\begin{array}{l}10 \mu \mathrm{g} \text { BD in a nebulised } \\
\text { solution }\end{array}$ & $(66)$ \\
\hline RhACE2 (APN01) & - & NCT04335136 & Phase II & - & $(52)$ \\
\hline NK cells & - & NCT04280224 & Phase I & $\begin{array}{l}0.1-0.2 \times 10^{7} \text { cells } / \mathrm{kg} \text { of body } \\
\text { weight twice weekly }\end{array}$ & (54) \\
\hline Thalidomide & - & NCT04273529 & Phase II & $\begin{array}{l}100 \mathrm{mg} \text { PO every night for } \\
14 \text { days }\end{array}$ & (69) \\
\hline Fingolimod & - & NCT04280588 & Phase II & $\begin{array}{l}0.5 \mathrm{mg} \text { PO OD for } 3 \text { consecutive } \\
\text { days }\end{array}$ & $(72)$ \\
\hline Dexamethasone* & - & NCT04395105 & Phase III & $\begin{array}{l}16 \mathrm{mg} \mathrm{IV} \mathrm{for} \mathrm{first} 5 \text { days followed } \\
\text { by } 8 \mathrm{mg} \text { IV for next } 5 \text { days }\end{array}$ & (77) \\
\hline Enoxaparin** & - & NCT04359277 & Phase III & $1 \mathrm{mg} / \mathrm{kg}$ every $12 \mathrm{~h} \mathrm{SC}$ & (78) \\
\hline
\end{tabular}

$P O$ - Oral administration; $B D$ - Twice daily; $T I D$ - Thrice daily ; $I V$ - Intravenous ; $N S$ - Normal Saline; SC-Subcutaneously; DIC- Disseminated intravascular coagulation; VTE- Venous thromboembolism; INF $\alpha$ - interferon- $\alpha$; RhACE2- Recombinant human angiotensin-converting enzyme-2; NK cells- Natural killer cells ; LPR-Lopinavir; RTR- Ritonavir

*Recommended to use in patient with hyperactive immune system-cytokine syndrome

**Recommended to use in patients with evidence of DIC/VTE 


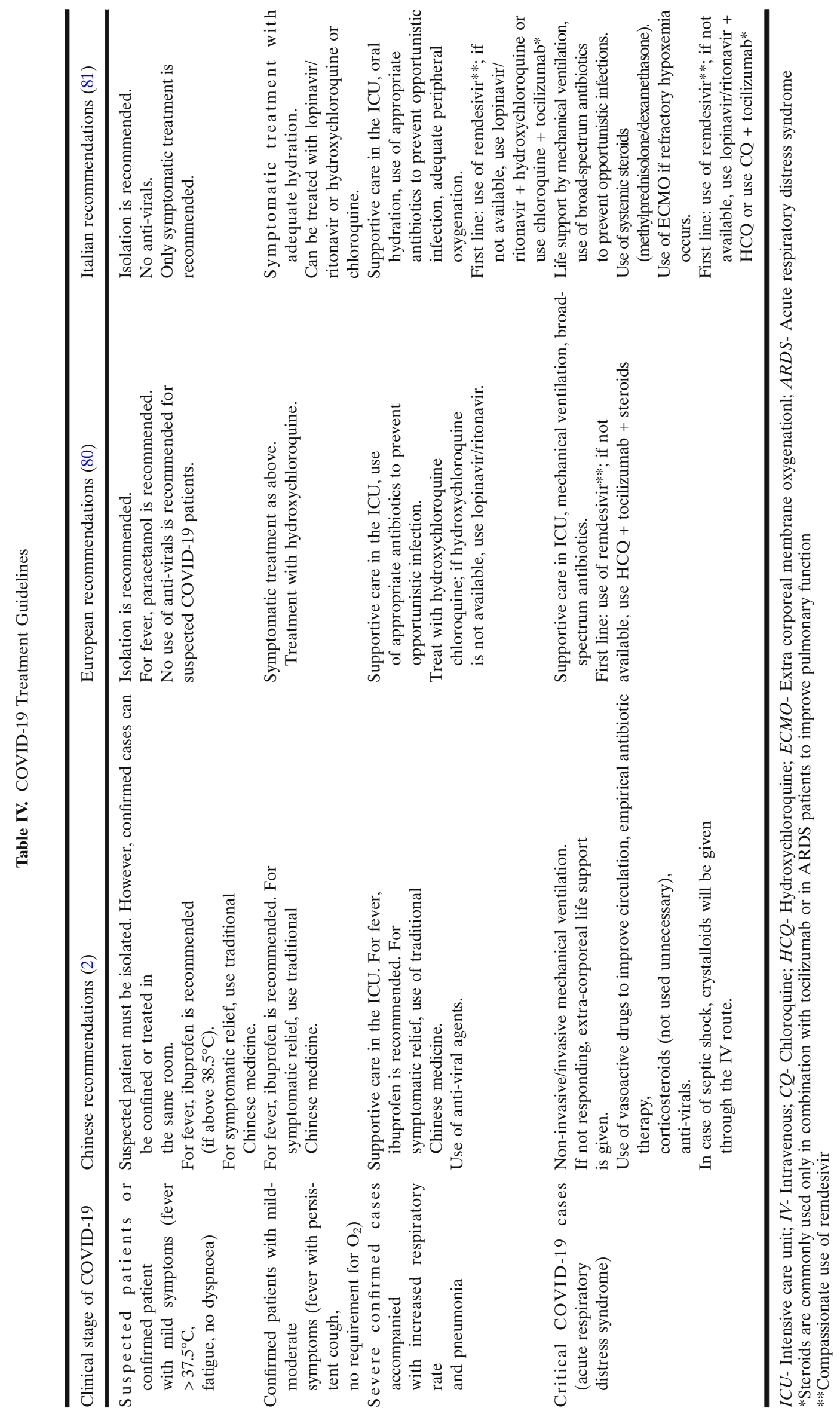


Table V. Emerging COVID-19 (Pipeline) Vaccines

\begin{tabular}{|c|c|c|c|c|c|}
\hline Nature of vaccine & $\begin{array}{l}\text { Target of } \\
\text { vaccine }\end{array}$ & $\begin{array}{l}\text { Principal developer } \\
\text { of vaccine }\end{array}$ & Country & Clinical trial status & Reference \\
\hline DNA Vaccine (INO-4800) & Spike (S) Protein & Inovio Pharmaceuticals & USA & $\begin{array}{l}\text { Phase I } \\
\text { NCT04336410 }\end{array}$ & $(90)$ \\
\hline \multirow[t]{2}{*}{ Non-replicating virus } & \multirow[t]{2}{*}{ Spike (S) protein } & University of Oxford & UK & $\begin{array}{l}\text { Phase I/II trial } \\
\text { NCT04324606 }\end{array}$ & $(91)$ \\
\hline & & $\begin{array}{l}\text { Shenzhen Geno-Immune } \\
\text { Medical Institute }\end{array}$ & China & $\begin{array}{l}\text { Phase I/II } \\
\text { NCT04276896 }\end{array}$ & $(92)$ \\
\hline \multirow[t]{2}{*}{ Inactivated vaccine } & \multirow[t]{2}{*}{ Entire virus } & $\begin{array}{l}\text { Sinovac Research and } \\
\text { Development Co. Ltd. }\end{array}$ & China and Brazil & $\begin{array}{l}\text { Phase II } \\
\text { NCT04352608 }\end{array}$ & (93) \\
\hline & & $\begin{array}{l}\text { Wuhan institute of } \\
\text { Biological Sciences }\end{array}$ & China & $\begin{array}{l}\text { Phase I } \\
\text { ChiCTR2000031809 }\end{array}$ & (94) \\
\hline mRNA vaccine & Spike (S) Protein & Moderna, USA & USA & $\begin{array}{l}\text { Phase I } \\
\text { NCT04283461 }\end{array}$ & (95) \\
\hline $\begin{array}{l}\text { Recombinant vaccine } \\
\quad \text { (adenovirus type- } 5 \text { vector) }\end{array}$ & Spike (S) Protein & CanSino Biologics & China & $\begin{array}{l}\text { Phase I clinical trial } \\
\text { Completed } \\
\text { NCT04313127 }\end{array}$ & $(96,97)$ \\
\hline Attenuated live vaccine & Entire virus & $\begin{array}{l}\text { Serum Institute of India in } \\
\text { collaboration with Codagenix }\end{array}$ & India and USA & Pre-clinical/animal studies & (98) \\
\hline
\end{tabular}

$D N A$ - Deoxyribonucleic acid; $m R N A$ - Messenger-Ribonucleic acid; $S$ - spike proteins

treatment is also recommended at this stage with the use of either lopinavir or ritonavir, if anti-malarials are contraindicated $(2,81)$.

\section{COVID-19 ARDS and Septic Shock}

Patients with severe pulmonary involvement could progress to the development of acute respiratory distress syndrome (ARDS) and septic shock. These patients should be aggressively shifted to medical emergency/ICU for vital sign monitoring and life support. In addition, respiratory depression should be managed by artificial ventilation either using non-invasive ventilation continuous positive airway pressure (CPAP)/bilevel positive airway pressure (BiPAP) or invasive mechanical ventilation to prevent hypoxemia. Patients with refractory hypoxemia are candidates for extracorporeal membrane oxygenation. In addition to life support and stabilisation of vitals, cases should be treated with broadspectrum antibiotics as well as glucocorticoids (to increase pulmonary function). COVID-19 septic shock patients should be administered intravenous crystalloids and vasoactive agents $(2,80,81)$.

\section{Recent Advancements in Symptomatic Treatment-Antithrombic Therapy}

With a more in-depth consideration of COVID-19 management, several researchers have observed the manifestation of disseminated intravascular coagulation (DIC) and venous thromboembolism (VTE) in COVID-19 patients with severe pulmonary involvement, evidenced by elevated levels of D-dimer (82). This coagulopathy may result in pulmonary thrombosis as well (83). To cope with COVID-19-induced coagulopathy, several treatment modalities, i.e. conventional DIC treatment options, have been tried. A case series has been reported utilising tissue plasminogen activators (TPA), but among three subjects, only one patient demonstrated a significant improvement in ARDS (84). Other treatment options for DIC may also be employed to address the development of secondary diseases, most probably cardiac dysfunction. Aspirin, with its proven cardioprotective effects, is being tested in an NIH clinical trial (NCT04365309) at Xijing Hospital, China (85). As entered in phase III clinical trials, enoxaparin is also showing better anti-coagulation among COVID-19 patients experiencing DIC or VTE (86).

\section{Convalescent Plasma/Immunoglobulin Utilisation}

The plasma of recovered patients contains immunoglobulins that can be used to treat patients with active viral disease. In 2014, clinical trials were launched by the NIH for the assessment of convalescent plasma therapy against MERS-COV-induced ARDS. However, the results were not satisfactory, and the clinical trial was stopped at phase II (NCT02190799) (87). This mode of treatment has also been evaluated regarding African Ebola virus. Moreover, based on knowledge of immunoglobulin responses obtained from trials organised against emerging viral respiratory infections in the last two decades, the FDA has recently given approval for the initiation of clinical trials for the purpose of assessing the efficacy and safety of this mode of therapy in the current pandemic. Recently, a randomized clinical trial was carried out to evaluate the benefits of convalescent plasma in critically ill COVID-19 patients, and they appeared with results showing little or no improvement. Moreover, the duration of disease also not appeared to be shortened by its addition in standard treatment of COVID-19 (88). However, there are risks associated with the administration of immunoglobulins, which is why it should be used only for severe or life-threatening COVID-19, according to the FDA advisory board (89).

\section{IMMUNIZATION: PIPELINE VACCINES}

The high rate of person-to-person spread makes this virus extremely contagious. The two most effective ways to 
alleviate the spread of a pandemic are protective precautionary measures and the use of a vaccine. Following the major concern of our review, vaccination is the mainstay for the prevention of any viral pandemic disease. Most essentially, the vaccine should be required to eliminate the high spread ability of COVID-19, which if not controlled will continue to drive the current pandemic. In order to develop a COVID-19 vaccine, the most commonly opted target is the spike (S) protein anchored around on the membrane of COVID-19 (50). Multiple platforms are currently working on vaccine development against COVID-19. Globally, important COVID-19 pipeline vaccination projects are described in Table V. Currently, the NIH has registered six vaccination trials, conducting in USA, UK and China.

\section{CONCLUDING REMARKS}

The alarming WHO statistics about active COVID-19 cases and deaths have already been discussed. Rapid diagnosis and timely management of this deadly infection are the necessary steps required to eradicate the COVID-19 pandemic. The current standard diagnostic approach still has some limitations regarding a lack of robustness and lengthy procedures. Alternate nucleic acid detection techniques including reverse transcriptase loopmediated isothermal amplification (RT-LAMP) and CRISPR as well as immunoassay-based devices are currently undergoing through approval phase. In addition, there is an urgent requirement for the development of effective drugs as well as vaccines in order to control this deadly pandemic, which is dangerous to the entire global population. The high death rate and unleashed spread of COVID-19 require effective drugs and vaccines as essential tools to limit the explosive spread of this disease. Many entities with already approved indications (repurposing) are being evaluated for COVID-19 treatment. Although inadequate progress has been made in this regard, remdesivir and dexamethasone treatment have led to a cautiously promising response. Moreover, a number of drugs are currently being investigated in clinical trials. In addition, six vaccines are currently being evaluated in clinical trials, but it will require almost a year or more to approve and market the safe and immunogenic vaccine.

\section{COMPLIANCE WITH ETHICAL STANDARDS}

Ethics Approval Not applicable.

\section{Consent for Publication Not applicable.}

Competing Interests The authors declare that they have no competing interests.

\section{REFERENCES}

1. Schünemann HJ, Zhang Y, Oxman AD. Distinguishing opinion from evidence in guidelines. BMJ. 2019;366:14606. https:// doi.org/10.1136/bmj.14606.
2. Jin Y-H, Cai L, Cheng Z-S, Cheng H, Deng T, Fan Y-P, et al. A rapid advice guideline for the diagnosis and treatment of 2019 novel coronavirus (2019-nCoV) infected pneumonia (standard version). Mil Med Res. 2020;7:4. https://doi.org/10.1186/s40779020-0233-6.

3. Organization WH. Coronavirus disease 2019 (COVID-19) Situation Report - 51. http://www.who.int/docs/default-source/ coronaviruse/situation-reports/20200311-sitrep-51-covid19.pdf?sfvrsn=1ba62e57_10 (2020). Accessed 04 April 2020.

4. Organization WH. Coronavirus disease (COVID-19) Situation Dashboard. http://covid19.who.int/ (2020). Accessed 08 July 2020.

5. Chu DKW, Pan Y, Cheng SMS, Hui KPY, Krishnan P, Liu Y, et al. Molecular diagnosis of a novel coronavirus (2019-nCoV) causing an outbreak of pneumonia. Clin Chem. 2020;66:549-55. https://doi.org/10.1093/clinchem/hvaa029.

6. Udugama B, Kadhiresan P, Kozlowski HN, Malekjahani A, Osborne M, Li VYC, et al. Diagnosing COVID-19: the disease and tools for detection. ACS Nano. 2020;14:3822-35. https:// doi.org/10.1021/acsnano.0c02624.

7. Vashist SK. In vitro diagnostic assays for COVID-19: recent advances and emerging trends. Multidisciplinary Digital Publishing Institute; 2020.

8. Corman VM, Landt O, Kaiser M, Molenkamp R, Meijer A, Chu DKW, et al. Detection of 2019 novel coronavirus (2019nCoV) by real-time RT-PCR. Eurosurveillance. $2020 ; 25: 2000045$. https://doi.org/10.2807/15607917.ES.2020.25.3.2000045.

9. Vashist SK. In vitro diagnostic assays for COVID-19: recent advances and emerging trends. Diagnostics. 2020;10:202. https:// doi.org/10.3390/diagnostics10040202.

10. Lim XF, Lee CB, Pascoe SM, How CB, Chan S, Tan JH, et al. Detection and characterization of a novel bat-borne coronavirus in Singapore using multiple molecular approaches. J Gen Virol. 2019;100:1363-74. https://doi.org/10.1099/jgv.0.001307.

11. Ai T, Yang Z, Hou H, Zhan C, Chen C, Lv W, et al. Correlation of chest CT and RT-PCR testing in coronavirus disease 2019 (COVID-19) in China: a report of 1014 cases. Radiology. 2020 200642. doi: https://doi.org/10.1148/radiol.2020200642.

12. Administration USFD. Xpert ${ }^{\circledR}$ Xpress SARS-CoV-2. http:// www.fda.gov/media/136314/download (2020). Accessed 4 April 2020.

13. Wang X, Zhong M, Liu Y, Ma P, Dang L, Meng Q, et al. Rapid and sensitive detection of COVID-19 using CRISPR/Cas12abased detection with naked eye readout, CRISPR/Cas12a-NER. Sci Bull. 2020. https://doi.org/10.1016/j.scib.2020.04.041.

14. Zhang Y, Odiwuor N, Xiong J, Sun L, Nyaruaba RO, Wei H, et al. Rapid molecular detection of SARS-CoV-2 (COVID-19) virus RNA using colorimetric LAMP. MedRxiv. 2020. https:// doi.org/10.1101/2020.02.26.20028373.

15. Administration USFD. ID NOW COVID-19 for use under an Emergency Use Authorization (EUA) only. https:// www.fda.gov/media/136525/download (2020). Accessed.

16. Carter LJ, Garner LV, Smoot JW, Li Y, Zhou Q, Saveson CJ, et al. Assay techniques and test development for COVID-19 diagnosis. ACS Publications; 2020.

17. Koczula KM, Gallotta A. Lateral flow assays. Essays Biochem. 2016;60:111-20. https://doi.org/10.1042/EBC20150012.

18. BioMedomics. COVID-19 IgM/IgG Rapid Test. http:// www.biomedomics.com/products/infectious-disease/covid-19-rt/ (2020). Accessed 4 April 2020.

19. Li Z, Yi Y, Luo X, Xiong N, Liu Y, Li S, et al. Development and clinical application of a rapid IgM-IgG combined antibody test for SARS-CoV-2 infection diagnosis. J Med Virol. 2020. https:// doi.org/10.1002/jmv.25727.

20. Diazyme. Diazyme DZ-Lite SARS CoV-2 IgM and IgG CLIA Kits. http://www.diazyme.com/dz-lite-sars-cov-2 (2020). Accessed 27 May 2020.

21. Diagnostics S. The world's first 2019-nCoV (SARS-CoV-2) CLIA Kits received CE mark. http://www.snibe.com/zh_en/ en newsView.aspx?id=576 (2020). Accessed 27 May 2020.

22. Deng C-X. The global battle against SARS-CoV-2 and COVID19. Int J Biol Sci. 2020;16:1676-7. https://doi.org/10.7150/ ijbs.45587. 
23. Long $\mathrm{C}, \mathrm{Xu} \mathrm{H}$, Shen Q, Zhang $\mathrm{X}$, Fan B, Wang C, et al. Diagnosis of the coronavirus disease (COVID-19): rRT-PCR or CT? Eur J Radiol. 2020;126:108961. https://doi.org/10.1016/ j.ejrad.2020.108961.

24. Chung M, Bernheim A, Mei X, Zhang N, Huang M, Zeng X, et al. CT imaging features of 2019 novel coronavirus (2019nCoV). Radiology. 2020 200230. doi: https://doi.org/10.1148/ radiol.2020200230.

25. Huang C, Wang Y, Li X, Ren L, Zhao J, Hu Y, et al. Clinical features of patients infected with 2019 novel coronavirus in Wuhan, China. Lancet. 2020;395:497-506. https://doi.org/ 10.1016/S0140-6736(20)30183-5.

26. Tian S, Xiong Y, Liu H, Niu L, Guo J, Liao M, et al. Pathological study of the 2019 novel coronavirus disease (COVID-19) through post-mortem core biopsies. Mod Pathol. 2020. https://doi.org/10.20944/preprints202003.0311.v1.

27. Xu X-W, Wu X-X, Jiang X-G, Xu K-J, Ying L-J, Ma C-L, et al. Clinical findings in a group of patients infected with the 2019 novel coronavirus (SARS-Cov-2) outside of Wuhan, China: retrospective case series. Bmj. 2020;368:m606. https://doi.org/ 10.20944/preprints202003.0001.v1.

28. Registry CCT. A randomized, open-label study to evaluate the efficacy and safety of lopinavir-ritonavir in patients with mild novel coronavirus pneumonia (COVID-19). http:// www.chictr.org.cn/showprojen. aspx ? proj=48991 (2020). Accessed 4 April 2020.

29. Cao B, Wang Y, Wen D, Liu W, Wang J, Fan G, et al. A trial of lopinavir-ritonavir in adults hospitalized with severe Covid-19. N Engl J Med. 2020;382:1787-99. https://doi.org/10.1056/ NEJMoa2001282.

30. Wang M, Cao R, Zhang L, Yang X, Liu J, Xu M, et al. Remdesivir and chloroquine effectively inhibit the recently emerged novel coronavirus $(2019-\mathrm{nCoV})$ in vitro. Cell Res. 2020;30:269-71. https://doi.org/10.1038/s41422-020-0282-0.

31. Mulangu S, Dodd LE, Davey RT Jr, Tshiani Mbaya O, Proschan M, Mukadi D, et al. A randomized, controlled trial of Ebola virus disease therapeutics. N Engl J Med. 2019;381:2293-303.

32. NIH. Study to evaluate the safety and antiviral activity of remdesivir (GS-5734 $\mathrm{TM}$ ) in participants with severe coronavirus disease (COVID-19). http://clinicaltrials.gov/ct2/show/ NCT04292899 (2020). Accessed 4 April 2020.

33. Reuters. Pakistan's Ferozsons to begin producing COVID-19 drug remdesivir. http://www.reuters.com/article/us-health-coronavirus-pakistan-remdesivi/pakistans-ferozsons-to-begin-producing-covid-19-drug-remdesivir-idUSKBN22R208 (2020). Accessed 27 May 2020.

34. Beigel JH, Tomashek KM, Dodd LE, Mehta AK, Zingman BS, Kalil AC, et al. Remdesivir for the treatment of Covid19-preliminary report. New England Journal of Medicine. 2020. http://dpi.org/10.1056/NEJMoa2007764. Accessed 8 July 2020.

35. NIH. Clinical study of Arbidol hydrochloride tablets in the treatment of pneumonia caused by novel coronavirus. http:// clinicaltrials.gov/ct2/show/NCT04260594 (2020). Accessed 4 April 2020.

36. Chen C, Huang J, Cheng Z, Wu J, Chen S, Zhang Y, et al. Favipiravir versus Arbidol for COVID-19: a randomized clinical trial. medRxiv. 2020. https://doi.org/10.1101/ 2020.03.17.20037432.

37. Sheahan TP, Sims AC, Zhou S, Hill C, Leist SR, Schaefer A, et al. An orally bioavailable broad-spectrum antiviral inhibits SARS-CoV-2 and multiple endemic, epidemic and bat coronavirus. bioRxiv. 2020. https://doi.org/10.1126/ scitranslmed.abb5883.

38. Gao J, Tian Z, Yang X. Breakthrough: chloroquine phosphate has shown apparent efficacy in treatment of COVID-19 associated pneumonia in clinical studies. Bioscience Trends. 2020;14:72-3. https://doi.org/10.5582/bst.2020.01047.

39. Rabi FA, Al Zoubi MS, Kasasbeh GA, Salameh DM, Al-Nasser AD. SARS-CoV-2 and coronavirus disease 2019: what we know so far. Pathogens. 2020;9:231. https://doi.org/10.13140/ RG.2.2.35430.37443.

40. Yao X, Ye F, Zhang M, Cui C, Huang B, Niu P, et al. In vitro antiviral activity and projection of optimized dosing design of hydroxychloroquine for the treatment of severe acute respiratory syndrome coronavirus 2 (SARS-CoV-2). Clin Infect Dis. 2020. https://doi.org/10.1093/cid/ciaa237.

41. NIH. Efficacy and Safety of hydroxychloroquine for treatment of pneumonia caused by 2019-nCoV ( $\mathrm{HC}-\mathrm{nCoV}$ ). http:// clinicaltrials.gov/ct2/show/NCT04261517 (2020). Accessed 4 April 2020.

42. Savarino A, Boelaert JR, Cassone A, Majori G, Cauda R. Effects of chloroquine on viral infections: an old drug against today's diseases. Lancet Infect Dis. 2003;3:722-7.

43. Sanders JM, Monogue ML, Jodlowski TZ, Cutrell JB. Pharmacologic treatments for coronavirus disease 2019 (COVID-19): a review. Jama. 2020;323:1824-36. https://doi.org/10.1001/ jama.2020.6019.

44. Register ECT. Treatment of coronavirus SARS-Cov2 respiratory infections with hydroxychloroquine. http:/www.clinicaltrialsregister.eu/ ctr-search/search?query=eudract_number:2020-000890-25 (2020). Accessed 4 April 2020.

45. Arshad S, Kilgore P, Chaudhry ZS, Jacobsen G, Wang DD, Huitsing K, et al. Treatment with hydroxychloroquine, azithromycin, and combination in patients hospitalized with COVID-19. Int J Infect Dis. 2020;97:396-403. https://doi.org/ 10.1016/j.ijid.2020.06.099.

46. NIH. The clinical study of carrimycin on treatment patients with COVID-19. http://clinicaltrials.gov/ct2/show/NCT04286503 (2020). Accessed 4 April 2020.

47. Caly L D, Druce G, Catton M A, Jans D M, Wagstaff K. The FDA-approved drug ivermectin inhibits the replication of SARS-CoV-2 in vitro. Antiviral Research. 2020;In press, preproof. doi: https://doi.org/10.1016/j.antiviral.2020.104787.

48. Wagstaff KM, Sivakumaran H, Heaton SM, Harrich D, Jans DA. Ivermectin is a specific inhibitor of importin $\alpha / \beta$-mediated nuclear import able to inhibit replication of HIV-1 and dengue virus. Biochem J. 2012;443:851-6. https://doi.org/10.1042/ BJ20120150.

49. Hoffmann M, Kleine-Weber H, Schroeder S, Krüger N, Herrler T, Erichsen S, et al. SARS-CoV-2 cell entry depends on ACE2 and TMPRSS 2 and is blocked by a clinically proven protease inhibitor. Cell. 2020;181:271-280.e8. https://doi.org/10.1016/ j.cell.2020.02.052.

50. Liu C, Zhou Q, Li Y, Garner LV, Watkins SP, Carter LJ, et al. Research and development on therapeutic agents and vaccines for COVID-19 and related human coronavirus diseases. ACS Publications; 2020.

51. Kuba K, Imai Y, Rao S, Gao H, Guo F, Guan B, et al. A crucial role of angiotensin converting enzyme 2 (ACE2) in SARS coronavirus-induced lung injury. Nat Med. 2005;11:875-9. https://doi.org/10.1038/nm1267.

52. NIH. Safety and immunogenicity study of 2019-nCoV vaccine (mRNA-1273) for prophylaxis SARS CoV-2 infection. http:// clinicaltrials.gov/ct2/show/NCT04283461 (2020). Accessed 4 April 2020.

53. Chen J, Lau YF, Lamirande EW, Paddock CD, Bartlett JH, Zaki SR, et al. Cellular immune responses to severe acute respiratory syndrome coronavirus (SARS-CoV) infection in senescent BALB/c mice: CD4+ T cells are important in control of SARS-CoV infection. J Virol. 2010;84:1289-301. https:// doi.org/10.1128/jvi.01281-09.

54. NIH. NK Cells Treatment for COVID-19. http:// clinicaltrials.gov/ct2/show/NCT04280224 (2020). Accessed 27 May 2020.

55. Herold T, Jurinovic V, Arnreich C, Hellmuth JC, von BergweltBaildon M, Klein M, et al. Level of IL-6 predicts respiratory failure in hospitalized symptomatic COVID-19 patients. medRxiv. 2020. https://doi.org/10.1101/2020.04.01.20047381.

56. NIH. Tocilizumab for SARS-CoV2 severe pneumonitis. http:// clinicaltrials.gov/ct2/show/NCT04315480 (2020). Accessed 4 April 2020.

57. NIH. Evaluation of the efficacy and safety of sarilumab in hospitalized patients With COVID-19. http://clinicaltrials.gov/ ct2/show/NCT04315298 (2020). Accessed 27 May 2020.

58. Keating GM. Bevacizumab: a review of its use in advanced cancer. Drugs. 2014;74:1891-925. https://doi.org/10.1007/s40265014-0302-9.

59. Medford ARL, Millar AB. Vascular endothelial growth factor (VEGF) in acute lung injury (ALI) and acute respiratory 
distress syndrome (ARDS): paradox or paradigm? Thorax. 2006;61:621-6. https://doi.org/10.1136/thx.2005.040204.

60. NIH. Bevacizumab in severe or critical patients with COVID-19 pneumonia (BEST-CP). http://clinicaltrials.gov/ct2/show/ NCT04275414 (2020). Accessed 27 May 2020.

61. Registry CCT. Comparative effectiveness and safety of ribavirin plus interferon-alpha, lopinavir/ritonavir plus interferon-alpha and ribavirin plus lopinavir/ritonavir plus interferon-alphain in patients with mild to moderate novel coronavirus pneumonia. http://www.chictr.org.cn/showprojen.aspx?proj=48782 (2020). Accessed 4 April 2020.

62. Russell CD, Millar JE, Baillie JK. Clinical evidence does not support corticosteroid treatment for 2019-nCoV lung injury. Lancet. 2020;395:473-5. https://doi.org/10.1016/S01406736(20)30317-2.

63. Kolilekas L, Loverdos K, Giannakaki S, Vlassi L, Levounets A, Zervas E, et al. Can steroids reverse the severe COVID-19 induced 'cytokine storm'? J Med Virol. 2020. https://doi.org/ 10.1002/jmv.26165.

64. Fadel R, Morrison A, Vahia A, Smith ZR, Chaudhry Z, Bhargava $P$, et al. Early short course corticosteroids in hospitalized patients with COVID-19. medRxiv. 2020. https:// doi.org/10.1093/cid/ciaa601.

65. NIH. The National Institutes of Health COVID-19 Treatment Guidelines Panel provides recommendations for dexamethasone in patients with COVID-19. http:// www.covid19treatmentguidelines.nih.gov/dexamethasone/ (2020). Accessed 8 July 2020.

66. NIH. Efficacy and safety of IFN- $\alpha 2 \beta$ in the treatment of novel coronavirus patients. http://clinicaltrials.gov/ct2/show/ NCT04293887 (2020). Accessed 27 May 2020.

67. Liu T, Guo F, Zhu X, He X, Xie L. Thalidomide and its analogues: a review of the potential for immunomodulation of fibrosis diseases and opthalmopathy. Exp Ther Med. 2017;14:5251-7. https://doi.org/10.3892/etm.2017.5209.

68. Haslett PAJ, Hanekom WA, Muller G, Kaplan G. Thalidomide and a thalidomide analogue drug costimulate virus-specific CD8+ T cells in vitro. J Infect Dis. 2003;187:946-55. https:// doi.org/10.1086/368126.

69. NIH. The efficacy and safety of thalidomide in the adjuvant treatment of moderate new coronavirus (COVID-19) pneumonia. http://clinicaltrials.gov/ct2/show/NCT04273529 (2020). Accessed 27 May 2020.

70. Dastan F, Tabarsi P, Marjani M, Moniri A, Hashemian SM, Tavakoli-Ardakani M, et al. Thalidomide against coronavirus disease 2019 (COVID-19): a medicine with a thousand faces. Iran J Pharm Res. 2020;19:1-2. https://doi.org/10.22037/ IJPR.2020.113369.14259.

71. McCormack PL. Natalizumab: a review of its use in the management of relapsing-remitting multiple sclerosis. Drugs. 2013;73:1463-81. https://doi.org/10.1007/s40265-013-0102-7.

72. NIH. Fingolimod in COVID-19. http://clinicaltrials.gov/ct2/ show/NCT04280588 (2020). Accessed 27 May 2020.

73. Registry CCT. The efficacy and safety of favipiravir for novel coronavirus-infected pneumonia: a multicenter, randomized, open, positive, parallel-controlled clinical study. http:// www.chictr.org.cn/showprojen. aspx? proj=50137 (2020). Accessed 4 April 2020.

74. Registry CCT. Study for the efficacy of chloroquine in patients with novel coronavirus pneumonia (COVID-19). http:// www.chictr.org.cn/showprojen. aspx ? proj=48968 (2020). Accessed 4 April 2020.

75. Registry CCT. A multicenter, randomized controlled trial for the efficacy and safety of tocilizumab in the treatment of new coronavirus pneumonia (COVID-19). http://www.chictr.org.cn/ showprojen.aspx?proj=49409 (2020). Accessed 4 April 2020.

76. Registry CCT. Favipiravir combined with tocilizumab in the treatment of novel coronavirus pneumonia (COVID-19)-a multicenter, randomized, controlled trial. http://www.chictr.org.cn/ showprojen.aspx?proj=51126 (2020). Accessed 4 april 2020.

77. NIH. Dexamethasone for COVID-19 related ARDS: a multicenter, randomized clinical trial. https://clinicaltrials.gov/ct2/show/ NCT04395105 (2020). Accessed 8 july 2020.
78. NIH. A randomized trial of anticoagulation strategies in COVID-19. https://clinicaltrials.gov/ct2/show/NCT04359277 (2020). Accessed 8 July 2020.

79. Yang Y, Islam MS, Wang J, Li Y, Chen X. Traditional Chinese medicine in the treatment of patients infected with 2019-new coronavirus (SARS-CoV-2): a review and perspective. Int J Biol Sci. 2020;16:1708-17. https://doi.org/10.7150/ijbs.45538.

80. Interim clinical guidance for adults with suspected or confirmed COVID-19 in Belgium. http://epidemio.wiv-isp.be/ID/Docum e n t s / C o vi d $19 /$ C O V I D -

19_InterimGuidelines_Treatment_ENG.pdf (2020). Accessed 4 April 2020.

81. Nicastri E, Petrosillo N, Bartoli TA, Lepore L, Mondi A, Palmieri F, et al. National Institute for the Infectious Diseases "L. Spallanzani", IRCCS. Recommendations for COVID-19 clinical management. Infect Disease Rep. 2020;12:8543. https:// doi.org/10.4081/idr.2020.8543.

82. Lauer SA, Grantz KH, Bi Q, Jones FK, Zheng Q, Meredith HR, et al. The incubation period of coronavirus disease 2019 (COVID-19) from publicly reported confirmed cases: estimation and application. Ann Intern Med. 2020;172:577-82. https:// doi.org/10.7326/M20-0504.

83. Marongiu F, Grandone E, Barcellona D. Pulmonary thrombosis in 2019-nCoV pneumonia? J Thromb Haemost. 2020;18:1511-3. https://doi.org/10.1111/jth.14818.

84. Wang J, Hajizadeh N, Moore EE, McIntyre RC, Moore PK, Veress LA, et al. Tissue plasminogen activator (tpa) treatment for COVID-19 associated acute respiratory distress syndrome (ARDS): a case series. J Thromb Haemost. 2020;18:1752-5. https://doi.org/10.1111/jth.14828.

85. NIH. Protective effect of aspirin on COVID-19 patients (PEAC). http://clinicaltrials.gov/ct2/show/NCT04365309 (2020). Accessed 27 May 2020.

86. Barnes GD, Burnett A, Allen A, Blumenstein M, Clark NP, Cuker A, et al. Thromboembolism and anticoagulant therapy during the COVID-19 pandemic: interim clinical guidance from the anticoagulation forum. J Thromb Thrombolysis. 2020 1. doi: https://doi.org/10.1007/s11239-020-02138-z.

87. NIH. Anti-MERS-CoV convalescent plasma therapy. http:// clinicaltrials.gov/ct2/show/NCT02190799 (2020). Accessed 4 April 2020.

88. Li L, Zhang W, Hu Y, Tong X, Zheng S, Yang J, et al. Effect of convalescent plasma therapy on time to clinical improvement in patients with severe and life-threatening COVID-19: a randomized clinical trial. JAMA. 2020. https://doi.org/10.1001/ jama.2020.10044.

89. Administration USFD. Investigational COVID-19 convalescent plasma - emergency INDs. http://www.fda.gov/vaccines-bloodbiologics/investigational-new-drug-ind-or-device-exemption-ideprocess-cber/investigational-covid-19-convalescent-plasmaemergency-inds (2020). Accessed 4 April 2020.

90. NIH. Safety, tolerability and immunogenicity of INO-4800 for COVID-19 in healthy volunteers. https://clinicaltrials.gov/ct2/ show/NCT04336410 (2020). Accessed 8 July 2020.

91. NIH. A study of a candidate COVID-19 vaccine (COV001). http://clinicaltrials.gov/ct2/show/NCT04324606 (2020). Accessed 27 May 2020.

92. NIH. Immunity and safety of Covid-19 synthetic minigene vaccine. https://clinicaltrials.gov/ct2/show/NCT04276896 (2020). Accessed 8 July 2020.

93. NIH. Safety and immunogenicity study of inactivated vaccine for prophylaxis of SARS CoV-2 infection (COVID-19). https:// clinicaltrials.gov/ct2/show/NCT04352608 (2020). Accessed 8 July 2020.

94. Registry CCT. A randomized, double-blind, placebo parallelcontrolled phase I/II clinical trial for inactivated novel coronavirus pneumonia vaccine (Vero cells). http:// www.chictr.org.cn/showprojen.aspx? proj=52227 (2020). Accessed 8 July 2020.

95. NIH. Safety and immunogenicity study of 2019-nCoV vaccine (mRNA-1273) for prophylaxis of SARS-CoV-2 infection (COVID-19). https://clinicaltrials.gov/ct2/show/NCT04283461 (2020). Accessed 8 July 2020. 
96. NIH. Phase I clinical trial of a COVID-19 vaccine in 18-60 healthy adults (CTCOVID-19). https://clinicaltrials.gov/ct2/ show/NCT04313127 (2020). Accessed 8 July 2020.

97. Zhu F-C, Li Y-H, Guan X-H, Hou L-H, Wang W-J, Li J-X, et al. Safety, tolerability, and immunogenicity of a recombinant adenovirus type-5 vectored COVID-19 vaccine: a doseescalation, open-label, non-randomised, first-in-human trial. Lancet. 2020;395:1845-54. https://doi.org/10.1016/S01406736(20)31208-3.
98. AReNA CT. Serum Institute of India brings Covid-19 vaccine into animal testing. http://www.clinicaltrialsarena.com/news/serum-institute-india-covid-19-vaccine/ (2020). Accessed 4 April 2020.

Publisher's Note Springer Nature remains neutral with regard to jurisdictional claims in published maps and institutional affiliations. 